\title{
Correction to: Increasing Verbal Interaction in Children with Autism Spectrum Disorders Using Audio Script Procedure
}

\author{
Cetin Topuz ${ }^{1} \cdot$ Burcu Ulke-Kurkcuoglu ${ }^{1}$ (D)
}

Published online: 1 October 2019

(c) Springer Science+Business Media, LLC, part of Springer Nature 2019

\section{Correction to: J Autism Dev Disord \\ https://doi.org/10.1007/s10803-019-04203-w}

The original version of the article contains an error in table and figures. The corrected Table 1 and Figs. 1, 2, and 3 are given below. The original version of this article was revised

Note:

1. Refer the attachment for Figs. 1, 2, and 3.

2. In Table 1 under GECDA column, ED must be changed as LD.

3. In Table 1 under the table ED emotional development must be changed as LD language development (refer attachment).

Publisher's Note Springer Nature remains neutral with regard to jurisdictional claims in published maps and institutional affiliations.

The original article can be found online at https://doi.org/10.1007/ s10803-019-04203-w.

Burcu Ulke-Kurkcuoglu

bulkekurkcuoglu@anadolu.edu.tr

1 Research Institute for Individuals with Disabilities, Anadolu University, 26470 Eskisehir, Turkey 
Table 1 Participant descriptions

\begin{tabular}{|c|c|c|c|c|c|c|c|}
\hline \multirow[t]{2}{*}{ Child } & \multirow[t]{2}{*}{ Diagnosis } & \multirow[t]{2}{*}{ Gender } & \multirow[t]{2}{*}{ Age } & \multirow[t]{2}{*}{ GECDA } & \multicolumn{2}{|l|}{ TELD-TR } & \multirow[t]{2}{*}{ ASIS } \\
\hline & & & & & RLD & ELD & \\
\hline Ege & $\begin{array}{l}\text { Pervasive developmental } \\
\text { disorder }\end{array}$ & M & 60 Months & $\begin{array}{l}\text { Within the average point } \\
\text { in PMG/CD } \\
\text { Under the lower border- } \\
\text { line in LD } \\
\text { At the lower borderline } \\
\text { in SED }\end{array}$ & $\begin{array}{l}\text { Under the average point } \\
\text { in RLD. Equivalent to } \\
40 \text { months }\end{array}$ & $\begin{array}{l}\text { Poor in ELD. Equivalent } \\
\text { to } 40 \text { months }\end{array}$ & $\begin{array}{l}81 \\
\text { (Bor- } \\
\text { der } \\
\text { IQ)- } \\
\text { ID }\end{array}$ \\
\hline Can & $\begin{array}{l}\text { Pervasive developmental } \\
\text { disorder }\end{array}$ & M & 82 Months & $\begin{array}{l}\text { Under the average point } \\
\text { in PMG } \\
\text { Under the lower border- } \\
\text { line in CD/LD } \\
\text { Within the average point } \\
\text { in SED }\end{array}$ & $\begin{array}{l}\text { Very poor in RLD. } \\
\text { Equivalent to } \\
28 \text { months }\end{array}$ & $\begin{array}{l}\text { Very poor in ELD. } \\
\text { Equivalent to } \\
38 \text { months }\end{array}$ & 74-ID \\
\hline Ali & $\begin{array}{l}\text { Pervasive developmental } \\
\text { disorder }\end{array}$ & M & 63 Months & $\begin{array}{l}\text { At the lower borderline } \\
\text { in PMG } \\
\text { Under the lower border- } \\
\text { line in CD/LD/SED }\end{array}$ & $\begin{array}{l}\text { Very poor in RLD. } \\
\text { Equivalent to } \\
28 \text { months }\end{array}$ & $\begin{array}{l}\text { ELD is equivalent to } \\
14 \text { months }\end{array}$ & 74-ID \\
\hline
\end{tabular}

$M$ Male, $P M G$ psychomotor development, $C D$ cognitive development, $L D$ language development, $S E D$ socio-emotional development, $R L D$ receptive language development, $E L D$ expressive language development, $I D$ intellectual disability 
Fig. 1 The number of total initiations during baseline, intermittent probe, and maintenance sessions

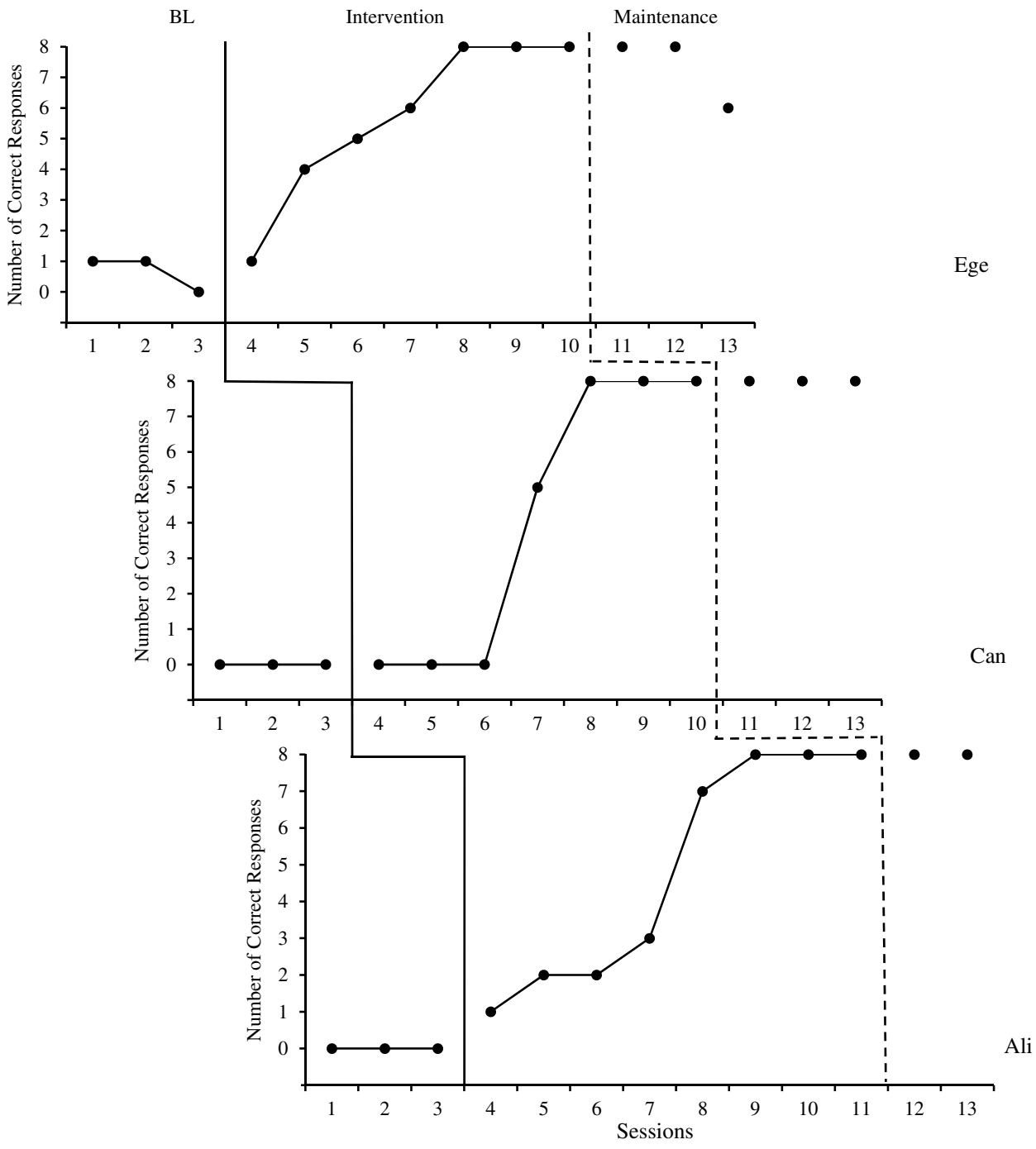


Fig. 2 The number of scripted, unscripted and novel initiations during baseline, intermittent probe, and maintenance sessions

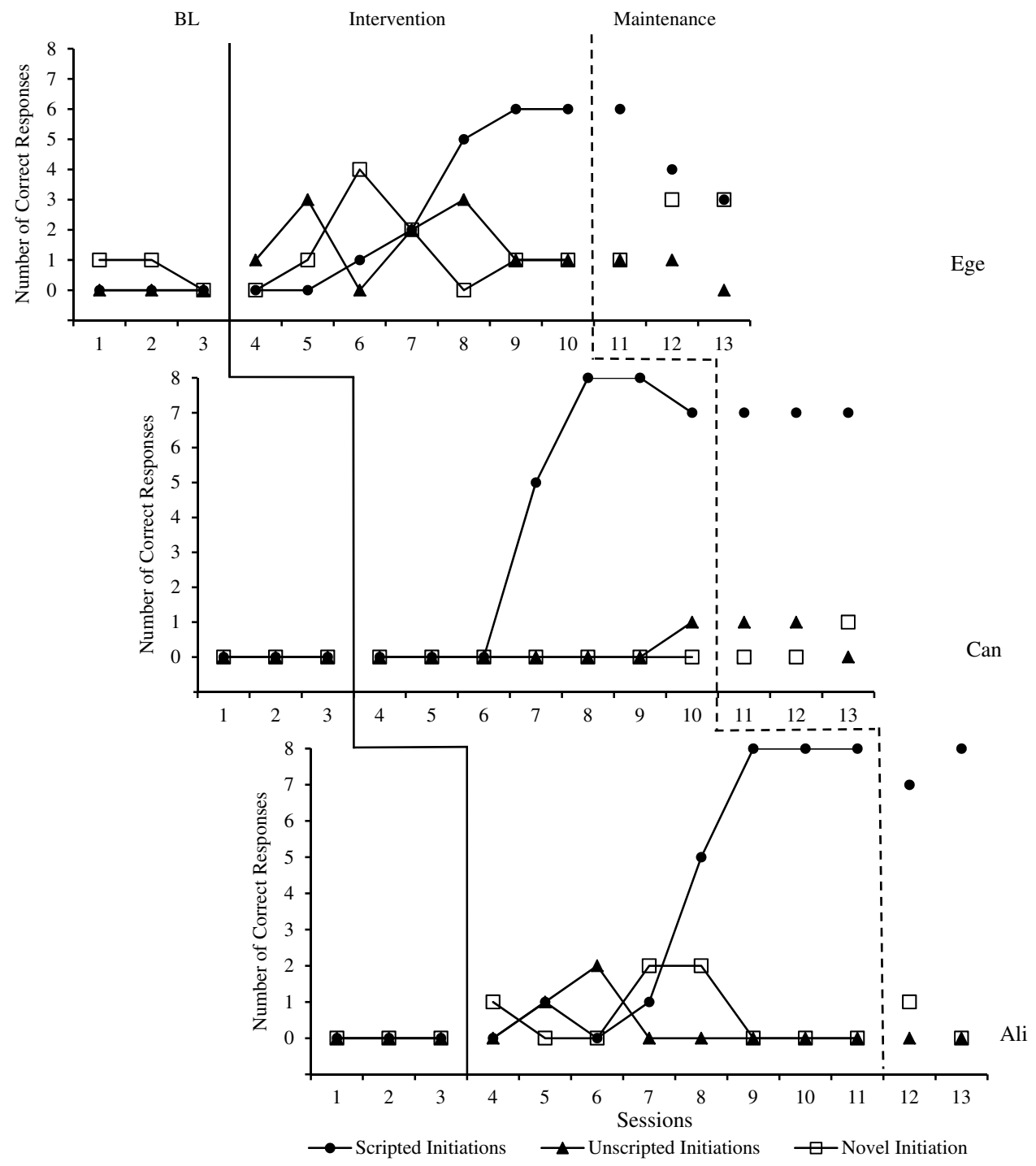


Fig. 3 The number of initiations during baseline and intervention sessions

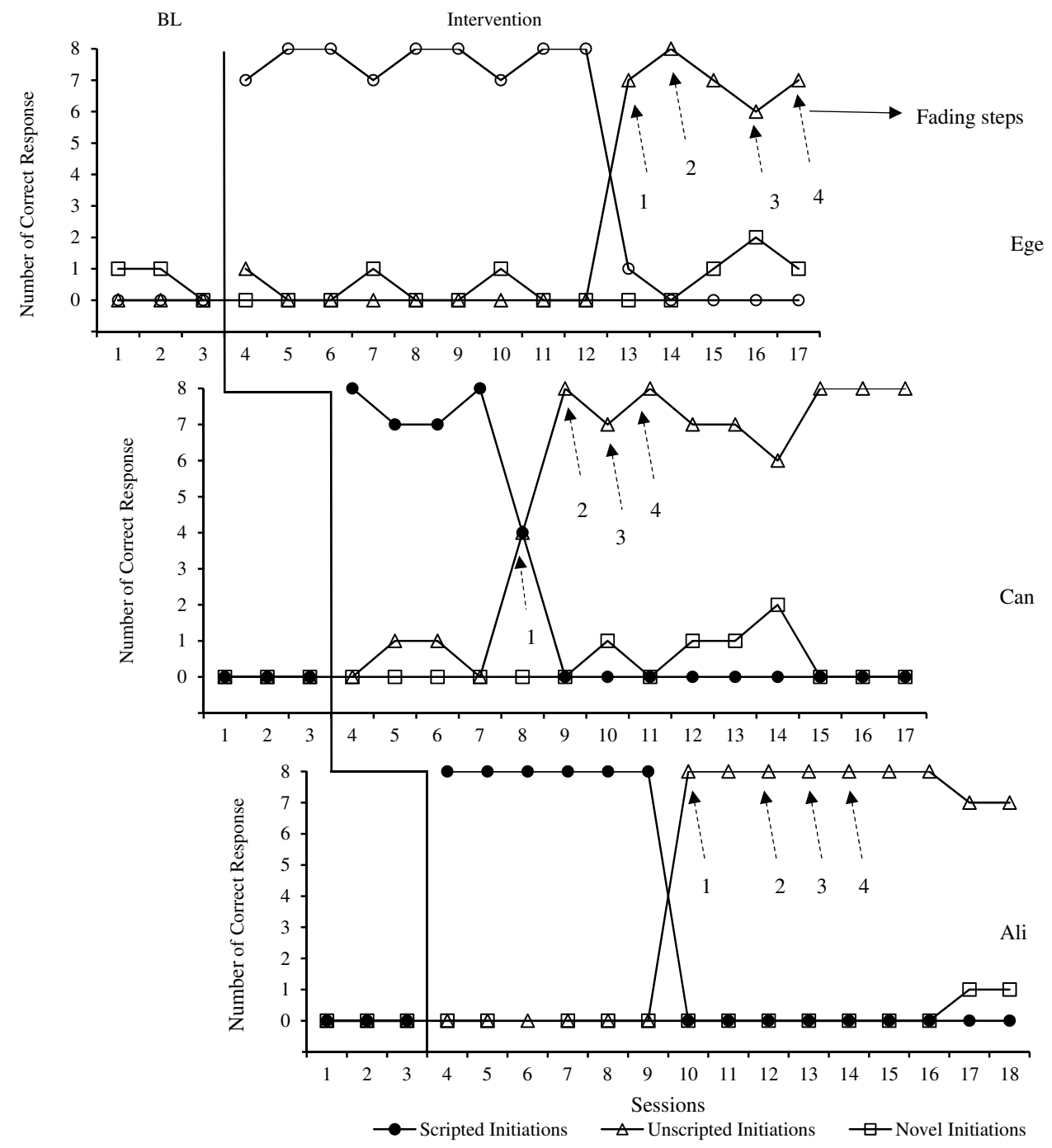

